DOI 10.18551/rjoas.2020-08.11

\title{
THE INFLUENCE OF INNOVATION, CUSTOMER VALUE AND CUSTOMER EMPOWERMENT ON CUSTOMER SATISFACTION
}

\author{
Yuniari Gusti Agung Ayu Dea Dwi, Giantari I Gusti Ayu Ketut \\ Faculty of Economics and Business, University of Udayana, Bali, Indonesia \\ *E-mail: deayuniari@gmail.com
}

\begin{abstract}
To continuously satisfy the ever-changing needs and desires of consumers is a challenge frequently faced by companies. In order to survive in the competition, companies must improve and develop strategies that can increase customer satisfaction. The purpose of this study is to analyze the influence of innovation, customer value and customer empowerment on customer satisfaction. The population in this study is the outpatients of the Regional General Hospital of Tabanan, with a total sample of 105 patients. The data were collected using questionnaires. The analysis technique used is the Structural Equation Model (SEM) with the SmartPLS 3.0 as the analysis tool. The analysis results showed that customer value, customer empowerment and innovation have a positive and significant influence on customer satisfaction. The results of this study are expected to provide insights for the management of hospitals to create effective strategies to improve patient satisfaction.
\end{abstract}

\section{KEY WORDS}

Customer value, customer empowerment, innovation, customer satisfaction.

The needs and desires of consumers are continuously evolving and frequently changes (Rogers, 2011). Mothe and Brion (2008) suggested that companies should try to satisfy the diverse needs of consumers and improve their satisfaction. Customer satisfaction is essentially the goal of a business. By improving customer's satisfaction, firms are more able to maintain their relationships and develop customer loyalty which is beneficial for the company (Basu Swastha, 2014). To survive in the competition, firms must improve and develop strategies that can increase customer satisfaction.

Consumer satisfaction can be achieved through innovations that improve the product or service provided by the firm (Bonner et al., 2002 and Tsinopoulos, 2012). Innovation must be customer-oriented and able to satisfy customers (Nemati et al., 2010). The essence of innovation from a marketing perspective is being able to offer customers with something unique, fulfill their needs, and improve their satisfaction (Simon and Honore, 2012). Gil et al. (2014) found that innovation and satisfaction are significantly related.

The success of service innovation in achieving consumer satisfaction depends on consumer value (Sekhon et al., 2015). Lin et al. (2013) and Sekhon et al. (2015) stated that innovation in several aspects has a positive influence on consumer value. Service innovation can create or improve consumer value (Flint et al., 2014). Ryu et al. (2010) also stated that service innovation and consumer value are closely related. Chiou (2004) revealed that perceived customer value is an important driver of customer satisfaction. The perceived quality of service and consumer value are two factors that determine satisfaction (McDougall and Levesque, 2000). However, the research conducted by Mmahmoud et al. (2017) found that innovation is not directly related to customer satisfaction, but the relationship is mediated by customer value.

O'Cass and Ngo (2011) showed that one of the most effective way to improve customer satisfaction is by empowering the consumers themselves. Hunter and Garnefeld (2008) concluded that customer empowerment has a positive influence on customer satisfaction. During the customer empowerment process, customers tend to feel appreciated and have a sense of belonging (Grissemann and Stokburger, 2012; and Franke et al., 2010). Customer empowerment can be a solution to overcome the challenges faced by marketers in providing the right product and price, as well as improve customer satisfaction (Salerno, 
2013) Mahr et al. (2014) and Fuchs and Schreier (2011) stated that customer empowerment contribute to innovation through the generation of new ideas or the selection of finished products before it is marketed.

\section{LITERATURE REVIEW AND RESEARCH HYPOTHESES}

The influence of innovation on customer satisfaction. The essence of innovation from a marketing perspective is to offer unique products to consumers, to fulfill their needs, and improve their satisfaction (Simon and Honore, 2012). Consumer satisfaction can be achieved by making innovations that lead to product or service improvements (Bonner et al., 2002 and Tsinopoulos, 2012). Gil et al. (2014) revealed that innovation and customer satisfaction are significantly related. Based on the discussed findings, the following hypothesis is formulated:

$\mathrm{H} 1$ : Innovation has a positive and significant influence on customer satisfaction.

The influence of innovation on customer value.Service innovation can be considered as a value creation activity (Slater and Narver, 2014). Service providers can improve consumer value through innovation (Chapman et al., 2002 and Flint et al., 2014). Lin et al. (2013) and Sekhon et al. (2015) stated that innovation in several aspects can positively influence consumer value. Ryu et al. (2010) also stated that service innovation and consumer value are closely related. Based on the discussed studies, the formulated hypothesis is as follows:

$\mathrm{H} 2$ : Innovation has a positive and significant influence on customer value.

The influence of customer value on customer satisfaction. Customer value creation has a positive and significant influence on customer satisfaction (Babin and Harris, 2014). Patterson and Spreng (1997), Ryu et al. (2010) and Chiou (2004) found that perceived consumer value is an important driver of customer satisfaction. McDougall and Levesque (2000) stated that perceived consumer value is the most prominent factor which determine customer satisfaction. Based on the results of previous studies, the following hypothesis is developed.

H3: Customer value has a positive and significant influence on customer satisfaction.

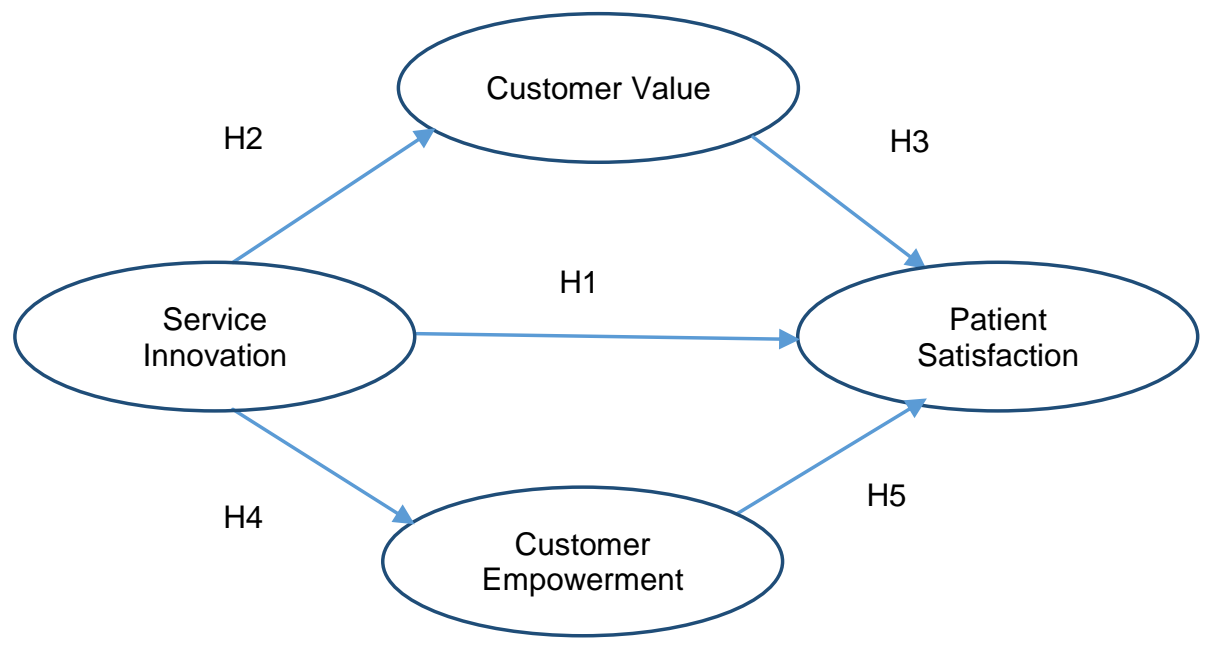

Figure 1 - Conceptual Framework

The influence of innovation on customer empowerment. According to Sarra and Hamouda (2018), customer empowerment reflects the believe of managers that customers can play a central role in innovation. Fuchs and Schreir (2011) also focused on customer empowerment in the context of new product development. Martovoy and Mention (2016) suggested that banks can benefit from the collaboration with their customers in all phases of the innovation process. Based on the discussions above, the formulated hypothesis is as follows:

$\mathrm{H} 4$ : Innovation has a positive and significant influence on customer empowerment. 
The influence of customer empowerment on customer satisfaction. Ramani and Kumar (2008) explained that customer empowerment leads to consumer satisfaction. O'Cass and Ngo (2011) showed that one of the most important methods to improve customer satisfaction is by empowering customers. Grissemann and Sauer (2012) and Franke et al. (2010) also stated that the direct involvement of customers in the empowerment process is able to create a sense of pride in the customer, which eventually stimulates their satisfaction towards the result. Based on the discussed results, the formulated hypothesis is as follows:

H5: Customer empowerment has a positive and significant influence on customer satisfaction.

Based on the literature review and the research hypothesis, the conceptual framework of this study is presented in Figure 1.

\section{METHODS OF RESEARCH}

This research is a quantitative associative study that discusses the relationship of customer value, customer empowerment, innovation, and customer satisfaction. The research was conducted at the Regional General Hospital of Tabanan. The population in this study is the outpatients of the Regional General Hospital of Tabanan with a total of 451,000 patients from 2017-2019. The sampling method used was the non-probability convenience sampling technique with a total sample of 105 patients. The data were collected through questionnaire which contained open-ended and closed-ended questions and used the 5point Likert scale.

The innovation construct in this study adapted and modified the indicators used in the research conducted by Rogers (2011), patient satisfaction adapted and modified the indicators used by Rahyuda and atmaja (2015), customer value adapted and modified the indicators used in the research conducted by Sanchez (2006) and customer empowerment adapted and modified the indicators used in the research conducted by Prentice et al. (2016). The analysis technique used in this study is the Structural Equation Model (SEM) and the analysis tool is the SmartPLS 3.0.

\section{RESULTS AND DISCUSSION}

The characteristics of the respondents were grouped into three criteria, based on their gender, age and last education level. Most of the patients were at an age of 55 years old. There were 48 men and 59 women among the respondents. In terms of their last education, 4 of the respondents graduated from elementary school, 18 graduated junior high school, 48 graduated high school, and 37 had an undergraduate degree.

The research instrument is deemed as valid if the value of the correlation coefficient is equal to or greater than 0.30 . Based on the results, all the variable instruments in this study have a correlation coefficient greater than 0.30. This means that the instruments have fulfilled the instrument validity requirements. The variable instrument is deemed as reliable if the Cronbach's Alpha ( $\alpha$ ) value is above 0.70 .30 respondents were used to test the reliability of the instrument. The result shows that all the variable instruments in this study have a Cronbach's Alpha $(\alpha)$ value above 0.70. This means that all instruments in this study are reliable.

The measurement model, examined based on the outer loading of the reflective indicators, is considered valid if the outer loading value is above 0.70 and/ or the t-statistics value is above 1.96. Since all the indicators have an outer loading value of greater than 0.70 , it proves that the model has fulfilled the convergent validity requirement. All the construct variables have a relatively good discriminant validity because the average variance extracted (AVE) values are greater than 0.50 and all the Cronbach's Alpha values exceed 0.60. The composite reliability and cronbach's alpha value is considered as good if it has a value of $>$ 0.60 . All the constructs in this study have a composite reliability and Cronbach's alpha value of greater than 0.6. 
The inner model is examined by assessing the relationship between constructs, the significance value and the R-square of the research model. The R-square value in this study is presented in Table 1.

Table 1 - The R-Square Value of the Dependent Variables

\begin{tabular}{lll}
\hline Variable & R Square & R Square Adjusted \\
\hline Customer empowerment & 0.504 & 0.498 \\
Customer satisfaction & 0.818 & 0.81 \\
Customer Value & 0.643 & 0.639 \\
\hline
\end{tabular}

Source: Computed primary data, 2020.

From the output table, it can be seen that 50.4 percent of the variability in the customer empowerment construct is influenced by the innovation variable, 81.8 percent of the variability in the customer value construct is influenced by the innovation variable, and 64.3 percent of the variability in the customer satisfaction construct is influenced by innovation, customer empowerment and customer value. The rest is influenced by other variables not included in the research model.

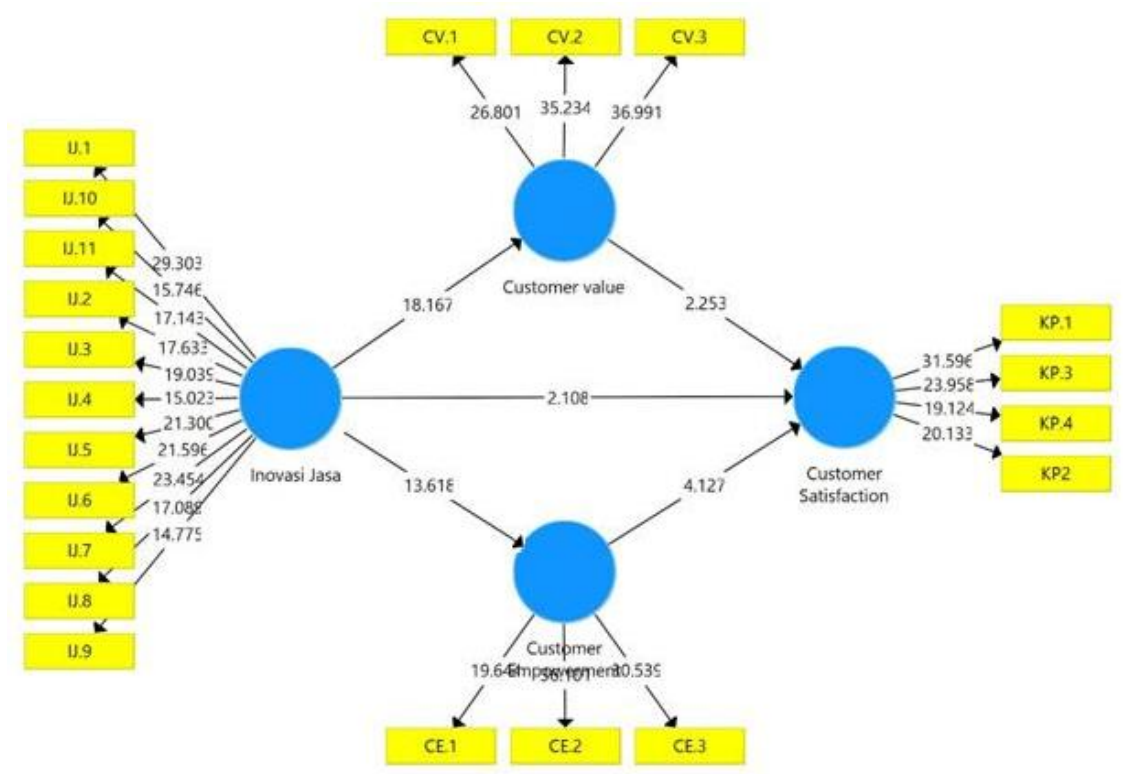

Figure 2 - Structural Model

The model is deemed to have a relevant predictive value if the Q-square is greater than $0(>0)$. The predictive relevance value is calculated using the following equation.

$$
\mathrm{Q} 2=1-(1-\mathrm{R} 12)(1-\mathrm{R} 22)=0,91
$$

The calculation result indicates that the $Q^{2}$ value is 0.91 , which is greater than 0 . Thus, the model is deemed to be good and has a predictive relevance value of 91 percent. This value can be interpreted as 91 percent of the variation in the customer satisfaction variable is explained by the variables examined in the study, while the remaining 9 percent is explained by other variables not included in this model.

Hypothesis Test Results. The hypotheses are examined by assessing the path coefficients, $t$-statistics, and the p-values. If the t-statistics is greater than the t-table (1.96), and the p-value is below 0.05 , the research hypothesis is accepted. The value of the path coefficients indicates the magnitude of the influence of a variable on other variables.

The influence of service innovation on customer satisfaction. The research result displayed in the table above shows that the influence of service innovation on customer satisfaction has a path coefficient of 0.315 and a t-statistic value of 2.108 . It can be 
concluded that service innovation has a significant and positive influence on customer satisfaction. Therefore, $\mathrm{H} 1$ is accepted. This means that the better the innovation and the more the people accept the service innovation implemented in RSUD Tabanan, the greater the satisfaction of their patients, vice versa. This result is in line with the studies conducted by Beckeman and Olsson (2011), Jensen et al., (2013), Ganesan et al. (2009), Lin et al. (2013) and Sekhon et al. (2015) which stated that innovation has a positive impact on customer satisfaction.

Table 2 - Path Coefficient

\begin{tabular}{|c|c|c|c|c|c|}
\hline & $\begin{array}{l}\text { Original } \\
\text { Sample }(\mathrm{O})\end{array}$ & $\begin{array}{l}\mathrm{T} \\
\text { Statistics } \\
\end{array}$ & $\begin{array}{l}\text { Required T } \\
\text { Statistics }\end{array}$ & $\begin{array}{l}\text { Direction of Path } \\
\text { Coefficient }\end{array}$ & Remarks \\
\hline $\begin{array}{l}\text { Service innovation } \rightarrow \text { Customer } \\
\text { satisfaction }\end{array}$ & 0.315 & 2.108 & 1.96 & Positive & Significant \\
\hline $\begin{array}{l}\text { Service innovation } \rightarrow \text { Customer } \\
\text { value }\end{array}$ & 0.802 & 18.167 & 1.96 & Positive & Significant \\
\hline $\begin{array}{l}\text { Service innovation } \rightarrow \text { Customer } \\
\text { Empowerment }\end{array}$ & 0.710 & 13.618 & 1.96 & Positive & Significant \\
\hline $\begin{array}{l}\text { Customer Empowerment } \rightarrow \\
\text { Customer satisfaction }\end{array}$ & 0.329 & 4.127 & 1.96 & Positive & Significant \\
\hline $\begin{array}{l}\text { Customer value } \rightarrow \text { Customer } \\
\text { satisfaction }\end{array}$ & 0.338 & 2.253 & 1.96 & Positive & Significant \\
\hline
\end{tabular}

Source: Computed primary data, 2020.

The influence of service innovation on customer value. The research result displayed in the path coefficient table shows that the influence of service innovation on customer value has a path coefficient of 0.802 and a t-statistic value of 18,167 . It can be concluded that service innovation has a significant and positive influence on customer value. Thus, $\mathrm{H} 2$ is accepted. This means that the better and the more the patients accept the service innovation implemented in RSUD Tabanan, the greater the value felt by these patients, vice versa. This result is consistent with the research conducted by Kandampully and Duddy (1999), Chapman et al. (2002), De Jong et al. (2003) and Flint et al. (2014) which stated that innovation has a positive impact on customer value.

The influence of customer value on customer satisfaction. The research result displayed in the path coefficient table shows that the influence of customer value on customer satisfaction has a path coefficient of 0.338 and a t-statistic value of 2.253. It can be concluded that customer value has a significant and positive influence on customer satisfaction. Thus, $\mathrm{H} 3$ is accepted. This means that the greater the value felt by the patients of RSUD Tabanan, the greater their satisfaction would be, vice versa. This result agrees to Spreng (1997), Ryu et al. (2010) and Chiou (2004) who revealed that perceived customer value is an important factor that can influence customer satisfaction, or in other words, customer value has a positive and significant influence on customer satisfaction.

The influence of service innovation on customer empowerment. The research result displayed in the path coefficient table shows that the influence of service innovation on customer empowerment has a path coefficient of 0.710 and a t-statistic value of 13.618. It can be concluded that service innovation has a significant and positive influence on customer empowerment. Thus, $\mathrm{H} 4$ is accepted. This means that the better the service innovation implemented, the greater the degree of customer empowerment in RSUD Tabanan, vice versa. This result is consistent with the research conducted by Fuchs and Schreier (2011) which stated that service innovation has a significant and positive influence on customer empowerment.

The influence of customer empowerment on customer satisfaction. The research result displayed in the path coefficient table shows that the influence of customer empowerment on customer satisfaction has a path coefficient of 0.329 and a t-statistics value of 4.127 . It can be concluded that customer empowerment has a significant and positive influence on customer satisfaction. Thus, H5 is accepted. This means that with a greater involvement of the patients in the customer empowerment process, the satisfaction of these patients will be higher, vice versa. This result is in line with the study conducted by O'Cass and Ngo (2011), 
Grissemann and Stokburger-Sauer (2012) and Franke et al. (2010) which revealed that customer empowerment has a significant and positive influence on customer satisfaction.

\section{CONCLUSION AND RECOMMENDATIONS}

The research results indicate that customer value, customer empowerment and innovation have a positive and significant influence on customer satisfaction. The results also show that customer value and customer empowerment is able to mediate the influence of innovation on customer satisfaction. Among the questionnaire statements related to service innovation, the lowest average value was obtained by the statement about the products being offered. Therefore, it is recommended for the hospital to test and evaluate their products and services first before these products and services are offered to customers. For the customer value variable, the statement with the the lowest average value is related to the characteristics of the services offered. Therefore, the hospital is suggested to describe more about the services available in the hospital. For the customer empowerment variable, the statement with the lowest average value is related to the accuracy of information obtained by patients and the speed to obtain this information. Thus, the hospital is suggested to prepare and provide information complying to the available standards so that the information can be easily obtained by patients. For the customer satisfaction variable, the statement with the lowest average score is related to quality. Thus, RSUD Tabanan is suggested to improve their quality of service in order to improve the satisfaction of their patients.

\section{REFERENCES}

1. Agrawal, A.K., Kaushik, A.K. and Rahman, Z. (2015), "Co-creation of Social Value through Integration of Stakeholders", Procedia-Social and Behavioral Sciences, Vol. 189, pp. 442- 448.

2. Artz, K.W., Norman, P.M., Hatfield, D.E.and Cardinal, L.B. (2010), "A Longitudinal Study of the Impact of R\&D, Patents, and Product Innovation on Firm Performance", Journal of Product Innovation Management, Vol. 27 No 5, pp. 725-740.

3. Al-Zu'bi, Z.M.F. and Tsinopoulos, C. (2012), "An outsourcing model for lead users: an empirical investigation", Production Planning \& Control, Vol. 24, No 4/5, pp. 337-346.

4. Anderson, E.W. and Sullivan, M.W. (1993), "The Antecedents and Consequences of Customer Satisfaction for Firms", Marketing Science, Vol. 12, No 2, pp. 125-43.

5. Anderson, E.W., Fornell, C., and Mazvancheryl, S.K. (2004), "Customer Satisfaction and shareholder Value", Journal of Marketing, Vol. 68 No 4, pp. 172-185.

6. Amit, R. Zott, C. 2006. Creating Value Through Business Model Innovation. MIT Sloan Management Review Edisi Sprong, 53(3).Retrieved Sept 18, 2013, From http:/management.wharton.upenn.edu/amitresearch/docs/2012/Amit_Creating Value_Business_Model_Innovation.pdf.

7. Berraies, S., Chaher, M. and Ben Yahia, K. (2014), "Knowledge Management Enablers, Knowledge Creation Process and Innovation Performance: An Empirical Study in Tunisian Information and Communication Technologies Sector", Business Management and Strategy Vol. 5 No 1, pp. 1-26.

8. Bonner, S.E., \& Sprinkle, G.B. (2002). The effect of monetary incentive on effort and task performance: theories, evidence and framework of research. Accounting, Organization and Society, 27(5), 303-345.

9. Chesbrough, H. 2006. Open Business Models: How To Thrive In The New Innovation Lanscape. American: Harvard Business School Press.

10. Christofi, A, Christofi, P, Sisaye, S 2012, 'Corporate sustainability: historical development and reporting practices', Management Research Review, vol. 35, no. 2, hh. 157-172.

11. Dharmmesta B.S (2014). Manajemen Pemasaran. BPFE: Yogyakarta.

12. Delafrooz, Narges 2013. The impact of service innovation on consumer satisfaction. 3 (2).

13. Dhewanto, Wawan. 2014. Manajemen Inovasi peluang sukses menghadapi perubahan. Yogyakarta: Andi. 
14. Fuchs, C. and Schreier, M. (2011), "Customer empowerment in New Product Development", Journal of Product Innovation Management, Vol. 28 No 1, pp. 17-32.

15. Fuchs, C., Prandelli, E. and Schreier, M. (2010), "The Psychological Effects of Empowerment Strategies on Consumers' Product Demand", Journal of Marketing, Vol. 74 No 1, pp. 65-79.

16. Flint, Daniel J. et al., 2002. "Exploring the Phenomenon of Customers' Desired Value Change in a Business-to-Business Context". Journal of Marketing: October 2002, Vol. 66, No. 4, pp. 102-117. http://journals.ama.org/.

17. Grissemann, U.S. and Stokburger-Sauer, N.E. (2012), "Customer Co-Creation of Travel Services: The Role of Company Support and Customer Satisfaction with the Co-Creation Performance", Tourism Management, Vol. 33 No 6, pp. 1483-1492.

18. Herrera U J,Sánchez C J,Pacheco H G, Sánchez C M. In-hospital outcome in patients with ST elevation myocardial infarction and right bundle branch block. A sub-study from RENASICA II, a national multicenter registry. Arch Cardiol Med 2010;80(3):154-158

19. Hair J.F. et.al (2014), "Multivariate Data Analysis With Reading", Fourth Edition, Prentice Hall. New Jersey.

20. Hristov, L. and Reynolds, J. (2015), "Perceptions and practices of innovation in retailing", International Journal of Retail and Distribution Management, Vol. 43 No. 2, pp. 126-147.

21. Kotler, Philip dan Gary Amstrong. 2018. Principles of Marketing. Edisi 15 Global Edition. Pearson.

22. Lin, C.Y., Marshall, D. and Dawson, J. (2013), "How Does Perceived Convenience Retailer Innovativeness Create Value for the Customer?". International Journal of Business and Economics, Vol. 12 No 2, pp. 171-179.

23. Mahr, D., Lievens, A. and Blazevic, V. (2014), "The Value of Customer Cocreated.

24. Knowledge during the Innovation Process", Journal of Product Innovation Management, Vol. 31 No 3, pp. 599-615.

25. McDougall, G.H. and Levesque, T. (2000), "Customer satisfaction with services: putting perceived value into the equation", Journal of Services Marketing, Vol. 14 No. 5, pp. $392-$ 410.

26. Mahmoud, M.A. and Hinson, R.E. (2012), "Market orientation, innovation and corporate social responsibility practices in Ghana's telecommunication sector", Social Responsibility Journal, Vol. 8 No. 3, pp. 327-346.

27. Mothe, C. and Brion, S. (2008), "Innovation: exploiter ou explorer?", Revue Française de Gestion, Vol. 34 No 187, pp.101-108.

28. Ngo, L.V; O'Cass, Aron, 2010, Value Creation Architecture And Engineering: A Business Model Encompassing The Firm-Customer DyadEuropean Business Review 22.5 (2010): 496-514.

29. O'Hern, M. S. and Rindfleisch, A. (2008), "Customer co-creation: A typology and research agenda", Review of Marketing Research, Vol. 6, pp. 84-106.

30. Rogers, E.M. (2011), Diffusion of Innovations, the Free Press, New York, NY.

31. Ryu, K., Han, H., and Kim, T.H., 2008, "The Relationships among Overall Quick-Casual Restaurant Image, Perceived Value, Customer Satisfaction, and Behavioral Intentions", International Journal of Hospitality Management, Vol. 27, pp. 459-469.

32. Perk J, Backer GD, Gohlke H, Graham I, Reiner Z, Verschuren WM, European guidelines on cardiovascular disease prevention in clinical practice. European Heart Journal. 2012; 33:1635-1701.

33. Prahalad CK, Ramaswamy. (2004). "Co-opting Customer Competence". Harvard Business Review. January-February: 79-81.

34. Patterson, P.G., Johnson, L.W. and Spreng, R.A. (1996), "Modeling the determinants of customer satisfaction for business-to-business professional services", Journal of the Academy of Marketing Science, Vol. 25 No. 1, pp. 4-17.

35. Peppers, D., \& Rogers, M. (2011). Managing Customer Relationships.

36. Prentice, C., Han, X.Y. and Li, Y.Q. (2016), "Customer empowerment to co-create service designs and delivery: scale development and validation", Services Marketing Quarterly, Vol. 37 No. 1, pp. 36-51. 
37. Sarra Berraies, Manel Hamouda, "Customer empowerment and firms' performance:The mediating effects of innovation and customer satisfaction", International Journal of Bank Marketing, https://doi.org/10.1108/IJBM-10-2016-0150.

38. Schreier M, Fuchs,C and Prandelli 2010), "The Psychological Effects of Empowerment Strategies on Consumers' Product Demand," Journal of Marketing, 74 (1), 65-79.

39. Salerno, F., Viviano, G., Manfredi, E. C., et al. (2013). Multiple Carrying Capacities from a management-oriented perspective to operationalize sustainable tourism in protected areas. Journal of Environmental Management, 128, 116-25. doi:10.1016/j.jenvman.2013.04.043.

40. Sanchez, R. and Iniesta M.A. (2006), "Consumer perception of value: literature review and a new conceptual framework". Journal of Consumer Satisfaction, Dissatisfaction and Complaining Behaviour, Vol. 19, pp. 40-58.

41. Sugiyono (2018). Statistika Untuk Penelitian (Cetakan Ke). Bandung: Alfabeta, Cv.

42. Slater and Narver, 2014, Does Competitive Moderate the Orientation Performance Relationship, Journal of Marketing, 58(1), pp. 46-55.

43. Sekhon, H.S., Al-Eisawi, D., Roy, S.K. and Pritchard, A. (2015), "Service excellence in UK retail banking: customers' perspectives of the important antecedents", International Journal of Bank Marketing, Vol. 33 No. 7, pp. 904-921.

44. Tjiptono, F. (2016). Pemasaran Jasa. Malang: Bayumedia.

45. Yuriansyah, A. L. 2013. Persepsi Tentang Kualitas Pelayanan, Nilai Produk Dan Fasilitas Terhadap Kepuasan Pelanggan. Management Analysis Journal. 2 (1). 